Journal of Engineering and Applied Sciences 14 (24): 9734-9739, 2019

ISSN: $1816-949 \mathrm{X}$

(C) Medwell Journals, 2019

\title{
Ameliorating Water Supply Problems in University of Nigeria, Nsukka
}

\author{
${ }^{1}$ C.N. Mama, ${ }^{1}$ C.C. Nnaji, ${ }^{2}$ I.P. Obe, ${ }^{1}$ C.D. Victor, ${ }^{1}$ D.C. Nwonu, ${ }^{1}$ I.A.Yakubu, \\ ${ }^{3}$ F.O. Okechukwu \\ ${ }^{1}$ Department of Civil Engineering, University of Nigeria, Nsukka, Nigeria \\ ${ }^{2}$ Department of Industrial Technical Education, University of Nigeria, Nsukka, Nigeria \\ ${ }^{3}$ Department of Home Science and Management, University of Nigeria, Nsukka, Nigeria
}

\begin{abstract}
Supply of abundant safe water has great influence on the health, economic productivity and quality of life of the people. Meeting this need is one of the major challenges facing both the rural and urban communities of Nigeria today. Therefore, improving water supply should be a major focus by the government, NGO's and other concerned bodies. There is disparity between the present daily water supply in the University of Nigeria, Nsukka by the university water works unit and the daily water requirements for the university residents. The estimated daily water requirement is $1,709,879 \mathrm{~L} /$ day and the estimated average quantity produced daily is $1,620,000 \mathrm{~L} /$ day but experiences $20-30 \%$ loss. Average of about $1,280,000 \mathrm{~L} /$ day reaches the consumers. Therefore, percentage of requirements satisfied is $74.86 \%$ implying that the university water works unit still needs about $25.14 \%$ of its current level of water supply to satisfy the total water requirement. The analysis of the water from the university water source shows that the quality indices of the sample were appreciably acceptable and the microbial analysis is within the WHO acceptable limit. The shortfalls in the quantity of the water supply in UNN are linked to the technological and management problems encountered by the university water works unit. Reactivation of the dormant and improving the existing water supply facilities in the university; modern technology approach using automated digital computer systems such as PLC and SCADA, among others should be used to monitor the whole distributing piping system.
\end{abstract}

Key words: Improving, water supply, boreholes, University of Nigeria, Nsukka, distributing piping system

\section{INTRODUCTION}

Understanding the fundamentals of a municipal water supply and delivery system is essential to closely examining the many features and options in designing an efficient water supply system. The purpose of municipal water delivery systems is to transport potable water from a water treatment facility to residential consumers, for use as drinking water, water for cooking, water for sanitary conditions and other water use in a domestic environment. University of Nigeria, Nsukka campus which is the study area have been having problems in supplying its need for water, a need that has come to assume gigantic proportions, since, the last three decades. Natural events such as droughts as well as the demands of an increasing population were permanent threats to the university water supply systems. Despite the construction of numerous boreholes and the involvement of several agencies in the improvement of water supply in the university, there are still several challenges militating against effective and sustainable service delivery in portable water supply in the university such as: poor feasibility studies, lack of appropriate maintenance culture, policy issues investment/funding and technological issues, these have led to water supply per capita in the campus to be below (Chima, 1989; Agunwamba, 1995; Agunwamba, 2000; Ubuoh et al., 2014).Therefore, problems of water supply in University of Nigeria, Nsukka are much in scale and complex that required a new approach and strategy for improved water resources sustainability. This necessitated this research.

\section{MATERIALS AND METHODS}

Location of the study area: University of Nigeria, Nsukka is located in Nsukka; Enugu State of Nigeria, at latitude $6^{\circ} 051^{\prime} 24^{\prime \prime} \mathrm{N}$ and longitude $7^{\circ} 23^{\prime} 45 \mathrm{E}^{\prime \prime} / 6.85669^{\circ} \mathrm{N}$ and $7.33332^{\circ} \mathrm{E}$. Variety of building exist here, first, we have modern bungalows and storied buildings which house the university staff. Secondly, there are other buildings (mostly storied) which house the academic Faculties and \& departmental buildings, laboratories, offices and business centers. The third group is the imposing hostels which at present have about 10,000 students, most of the residential houses are self-contained and possess modern amenities like taps, water closet system and boy's quarters. The houses here are often set in the midst of large lawns. A large proportion of university staff and students reside within the university (Eze, 1976). 


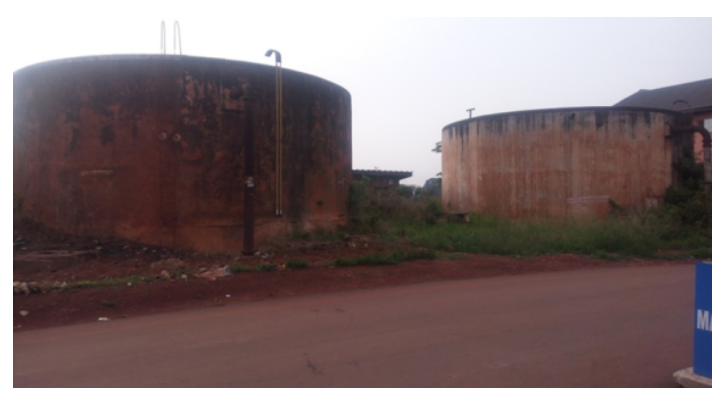

Fig. 1: Abandoned Odenigwe UNN twin reservoir. It has a combined capacity of $1376 \mathrm{~m}^{3}$. (Odenigwe, Nsukka)

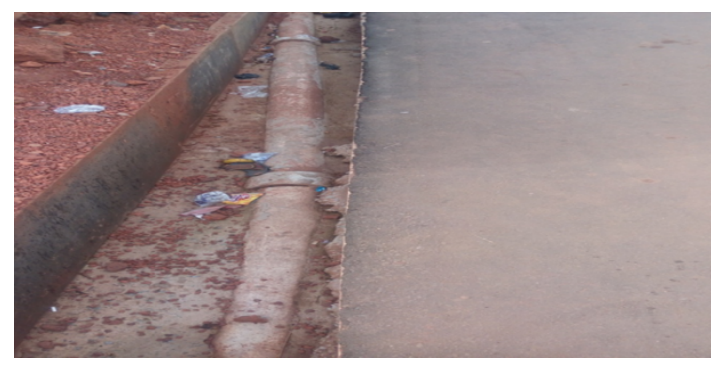

Fig. 2: Drainage line of the newly constructed Sam Onyishi Road. The drainage line was constructed on the main lines to the Odenigwe Reservoir, this could cause pipe bursting during the excavation of the drainage line

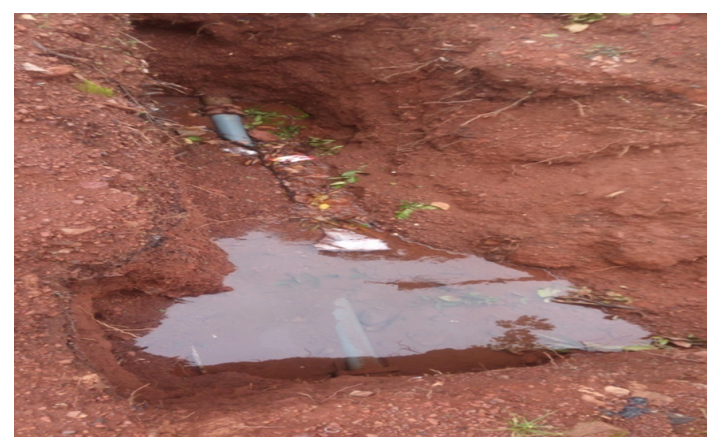

Fig. 3: Leaking pipe at one of the minor lines along Ikejiani Avenue, UNN

Sources of data: Relevant data concerning the quantity of water supply, the distribution network, generation systems and facilities, existing supply problems, their relative contributions and other water supply facilities in UNN were obtained from the water works department University of Nigeria, Nsukka and through oral interview, field works and laboratory work. Figure 1-6 show boreholes, non-positioned drainage line, leaking pipes and leaking control valve.

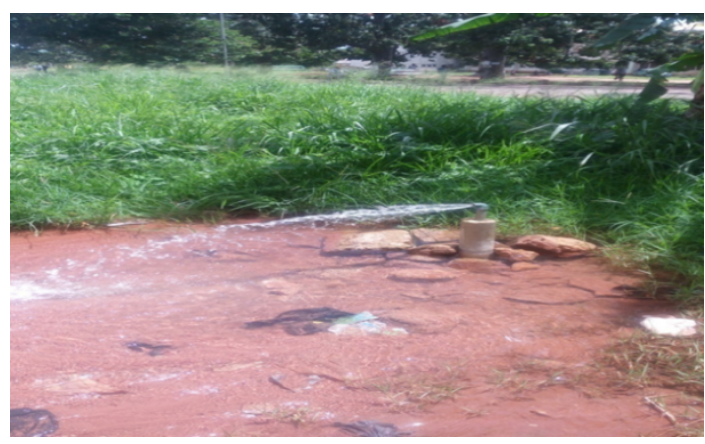

Fig. 4: SCC borehole 2 UNN

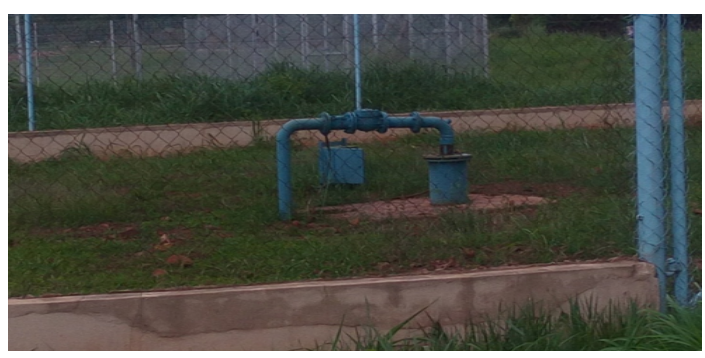

Fig. 5: SCC borehole 3 UNN

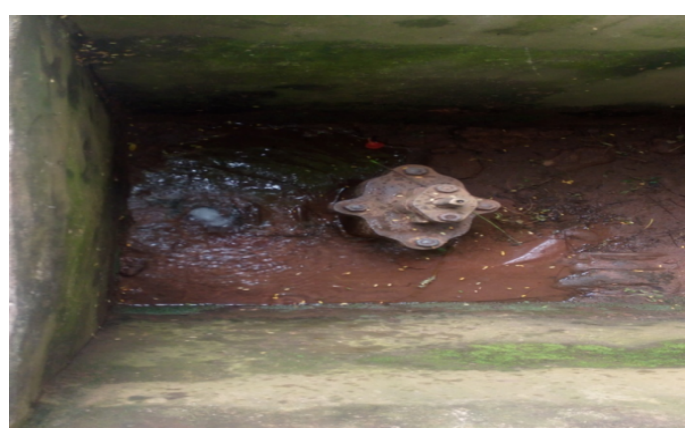

Fig. 6: Leaking control valve at Ikejiani street UNN

\section{RESULTS AND DISCUSSION}

The university water supply is controlled by the works department (water works unit). The water works unit is made up of:

- The generation unit

- Distribution unit

- Domestic water supply unit

Sources: Due to lack of surface water in the area, ground water is the only source of water in the university. Currently, there are about nine boreholes in the university located at different areas but only five are working. There are two borehole stations in the campus namely; the SCC 
borehole located at agric farm and the Franco borehole located opposite PG hostel UNN (Table 1 and 2). The boreholes are between 126-152 $\mathrm{m}$ in depth and are equipped with electrically driven submersible pumping units with stand-by generating power plants.

Storage: There are 3 main reservoirs within the university community, the shaft reservoir, one pipe system and two pipe system. One is located at Ugwu Edega, one behind works services department and the Odenigwe twin. Due to their elevations water is distributed by gravity flow. The Ugwu Edega reservoir is used to serve all the hostels and some streets within the campus. The works department reservoir is fed from Franco borehole and also serves the Franco hostels and environs. The Odenigwe twin reservoir has been out of service for long now. It used to serve the upland senior housing. Also low level reservoirs have been established at some strategic points in the university to act as standby in times of shortage and firefighting purposes (Hazen-Williams, 2009) (Table 3).

Daily water supply in UNN: The boreholes were supposed to be in $24 \mathrm{~h}$ operation daily but the irregular

Table 1: Borehole stations in UNN with the number of functional and non-functional borehole at each station

\begin{tabular}{lll}
\hline Borehole station & SCC & Franco \\
\hline Location & Agric farm & Franco \\
Functional & 3 & 2 \\
Not functional & 2 & 2 \\
Total & 5 & 4 \\
\hline
\end{tabular}

Table 2: Capacity of the boreholes in UNN

\begin{tabular}{ll}
\hline Variables & Capasity (L) \\
\hline $\begin{array}{l}\text { Number of current functional boreholes } \\
\text { Estimated daily average number of hours } \\
\text { of operation }\end{array}$ & 5 \\
$\begin{array}{l}\text { Estimated average quantity yield per } \\
\text { borehole per hour }\end{array}$ & 12 \\
$\begin{array}{l}\text { Total estimated average daily amount } \\
\text { produced by the } 5 \text { functional boreholes }\end{array}$ & $1,620,000 \mathrm{~L} /$ day \\
\hline
\end{tabular}

Table 3: Reservoirs in UNN with their capacities and locations

\begin{tabular}{lllc}
\hline Location & Capacity $(\mathrm{L})$ & Remarks & Elevation (m) \\
\hline Odenigwe hill & $1,376,000$ & Not functional & 495 \\
Works, UNN & 909,000 & Functional & 446 \\
Edega hill & $6,800,000$ & Functional & 510 \\
\hline
\end{tabular}

power supply and unsteadiness of the voltage at 415-420 V for which the pumps are designed to function greatly affect this order. Average of $12 \mathrm{~h}$ daily operation according to the operators at the boreholes is adopted for calculations (Table 4):

- Yield per borehole per hour is $27 \mathrm{~m}^{3} / \mathrm{h}=270,000 \mathrm{~L} / \mathrm{h}$

- We now sum the total daily discharge from the 5 boreholes, thus

- Daily discharge $\mathrm{Q}=5(27 \times 12)=1620 \mathrm{~m}^{3} /$ day $=$ $1,620,000 \mathrm{~L} /$ day

Total estimated water requirements by UNN residents:

- $\quad$ Students residential area I (girls' hostels) estimated daily water requirements $=506,880 \mathrm{~L} /$ day

- $\quad$ Students residential area II (PG and boys' hostels) estimated daily water requirements $=350,400 \mathrm{~L} /$ day

- Staff residential areas in the campus estimated daily water requirements $=375,120 \mathrm{~L} /$ day

- Estimated daily water requirements by other major sources $=477,479 \mathrm{~L} /$ day

- $\quad$ Total $=1,709,879 \mathrm{~L} /$ day

Major sources include daily water requirement from: refectories, power houses consumption rate, CEC consumption rate, firefighting consumption rate, laboratories, medical center consumption rate, swimming pool consumption rate, stadium, student's recreation centersconsumption rate, staff club consumption rate, banks consumption rate, etc (Fig. 7).

Deficiency in UNN daily water requirement: The total estimated daily water requirement by major consumers in $\mathrm{UNN}$ is $1,709,879 \mathrm{~L} /$ day. Without considering minor consumers, $1,709,879 \mathrm{~L} /$ day is $>1,280,000 \mathrm{~L} /$ day which is the highest daily water supplied for the week in Table $4,1,709,879-1,280,000=429,879 \mathrm{~L} /$ day. This shows that about 429,879 L/day shortage was encountered daily during that week. The estimated percentage satisfied is given as $429,879 / 1,709,879 \times 100=25.14 \%$. About $100-25.14=74.86 \%$.

Therefore, estimated percentage of the requirement satisfied $74.86 \%$ is implying that the university water works unit still need about $25.14 \%$ of its current level of

Table 4: Estimated water supply record for a week from the working boreholes in UNN for part of March, 2018

\begin{tabular}{|c|c|c|c|c|}
\hline Days & $\begin{array}{l}\text { Quantity } \\
\text { produced (L) }\end{array}$ & $\begin{array}{c}\text { Estimated percentage lost in } \\
\text { distribution lines for each day }(\%)\end{array}$ & Quantity lost (L) (20-30\%) & Quantity supplied (L) \\
\hline 6th May (Sun) & 1640000 & 26 & $1640000 \times 0.26=426000$ & $1640000-426000=1214000$ \\
\hline 7th May (Mon) & 1600000 & 20 & $1600000 \times 0.20=320000$ & $1600000-320000=1280000$ \\
\hline 8th May (Tue) & 1600000 & 21 & $1600000 \times 0.21=336000$ & $1600000-336000=1264000$ \\
\hline 9th May (Wed) & 1610000 & 22 & $1610000 \times 0.22=354000$ & $1610000-354000=1256000$ \\
\hline 10th May (Thur) & 1620000 & 23 & $1620000 \times 0.23=373000$ & $1620000-373000=1247000$ \\
\hline 11th May (Fri) & 1620000 & 24 & $1620000 \times 0.24=389000$ & $1620000-389000=1231000$ \\
\hline 12th May (Sat) & 1650000 & 28 & $1650000 \times 0.28=462000$ & $1650000-462000=1188000$ \\
\hline Total & 11340000 & - & 2660000 & 8680000 \\
\hline
\end{tabular}

Water works unit, UNN 


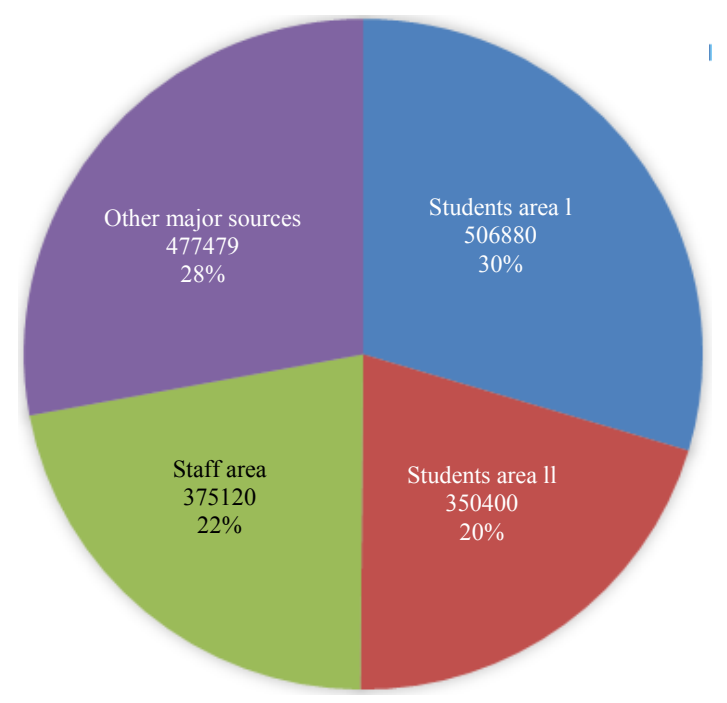

Fig. 7:Pie chart showing the estimated daily water requirements by the different areas in $\mathrm{UNN}$ in liters

Table 5: The physicochemical properties of sampled eater from Okpara hall tap water in UNN

\begin{tabular}{llll}
\hline Constituents & Results & Units & $\begin{array}{l}\text { WHO maximum } \\
\text { permitted level limit }\end{array}$ \\
\hline pH & 6.1 & - & $6.50-8.50$ \\
$\begin{array}{l}\text { Chloride } \\
\begin{array}{l}\text { Total dissolved } \\
\text { solids }\end{array}\end{array}$ & 3.880 & $(\mathrm{mg} / \mathrm{L})$ & 250.00 \\
$\begin{array}{l}\text { Biochemical } \\
\text { oxygen demand }\end{array}$ & 5.86 & $(\mathrm{mg} / \mathrm{L})$ & 1000 \\
$\begin{array}{l}\text { Coliform } \\
\text { Total viable count }\end{array}$ & 0.01 & $(\mathrm{mg} / \mathrm{L})$ & $\mathrm{N} / \mathrm{A}$ \\
\hline
\end{tabular}

water supply to satisfy the total daily water requirements. Therefore, it is obvious now that enough water is not produced in UNN by the water works unit to meet the daily water needs by the residents of the university community.

Levels of the physicochemical and bacteriological parameters of a sampled water from UNN water source, along with the recommended and approved WHO 2018 is shown in Table 5. From Table 5, the result of the water test shows that $\mathrm{pH}$, chloride, total dissolved solids, BOD, coliform and total viable count values all fell below the optimal values recommended and approved by WHO. (2018).

Reasons for shortfalls in UNN water supply: The problems affecting water supply and distribution can be categorized as technological and management problems.

Technological problem: These are problems due to the engineering components of the water supply system. e.g., inadequate power supply insufficient boreholes due to hydrological failure and construction failure; issue of old, burst and leaking pipes and lack of proper sewage disposal system.

Management problems: These are problems that have to do with the personnel's that handle the technical details, e.g., staff bureaucracy, staff welfare and maintenance/financial issues.

Improving existing facilities: The current water facilities on campus honestly need to be looked into as their states are despondent. Firstly, the number of boreholes has to be increased as out of nine only five are functional. Also, these boreholes are being grossly overworked such that the maximum yield is not being gotten.

The only close source of water supply for the campus is underground water source. The current yield per borehole per hour working for average is $27,000 \mathrm{~L}$. If the borehole is made to work for at least $16 \mathrm{~h} /$ day, then the minimum daily yield per borehole pumping for $16 \mathrm{~h}$ is: $16 \times 27,000=432,000 \mathrm{~L}$.

For the estimated daily water demand of $1,709,879 \mathrm{~L}$ plus other minor demands, maximum of about $2,500,000 \mathrm{~L} /$ day will be efficient or near to the quantity that will be adequate to satisfy the campus water needs. Number of boreholes required to serve the residents is $2,500,000 / 432,000=6$ boreholes.

Considering other unaccounted population/sources that use the university water daily, optimal daily operations of the nine boreholes in the university will be efficient for the current university water needs.

Cases of siting boreholes in aquiclude can be reduced by adopting proper geological and geophysical investigations before drilling. Construction of boreholes deeper into water bearing horizons will minimize the influence of seasonal variations in water level on yield. The problem of incrustation may be solved by surging the well with a plunger and causing alternation flow back and forth through the screen or in severe cases allowing hydrochloric acid to stand in the well for several hours. The maintenance of boreholes should be done monthly which involves checking; water quality, pumping rate of water, static water level, pump motor, servicing of the power generators and submersible and sanitation of the pump house and field.

The state of the pumping house is also a cause for concern as it's in a state of despair. Spare parts are lacking in all its entirety, so that, when there is minor breakdown substitution cannot be made, leading to a worse situation. Most of the booster pumps in the hostels that aid in lifting water to heights beyond the ability of the main pumps are either spoiled or vandalized. These pumps should be installed again, so that, water can easily flow up high elevations (Agunwamba, 2000). 
The clear water underground tank should be expanded to accommodate the much water that will be generated during optimal service of the boreholes:

- $\quad$ Storage required $=1$ day capacity

- Estimated quantity of water per day required for the university is $2,500,000 \mathrm{~L}$

- Volume of existing tank is 540,000

- Number of existing tanks $=2$

- $\quad$ Number of tanks required $=2,500,000 / 540,000=5$

- Six tanks with 540,000 L' capacity will be enough to store the generated water for the university community before distributing it.

The university is using grid pattern. The campus with well planned development and streets layout, the borehole sites and location of service reservoirs approximates the distribution system to the grid pattern with loop. Grid with loops should be adopted to improve water pressure. loops should be strategically located, so that as the campus develops the water pressure should be sustained.

Also, the number of connections in the distribution network should be minimized as much as possible because water is also lost due to connections:

\section{Water loss due to connections $=$ Quantity produced $\times 1000$ Number of connections}

Oral interview during field investigation shows that the original design of the water supply system is that the generated water after treatment should be sent to the reservoir through the main lines with high pressure and then distributed with gravitational force to the consumers but most times this pattern is not followed. Water from the generating station is pushed into the minor lines with high pressure causing much pipe burst. The reservoirs should be reactivated to restore the original design and reduce much water loss through, leakages and pipe burst. Capacity of the service reservoir for present water demand; the maximum estimated present daily requirement for the campus is about 2,500,000 L. To allow for uncertainties $40 \%$ of maximum daily flow will be the actual capacity for service reservoirs we shall adopt. Storage is $40 \%$ maximum daily flow. Capacity of service reservoir $=40 / 100 \times 2,500,000=1,000,000 \mathrm{~L}$.

If all the dormant existing reservoirs in the university are functioning, then the capacity of the existing reservoirs is:

- $\quad$ Odenigwe twin $=1,360,000 \mathrm{~L}$

- $\quad$ Edega $=680,000 \mathrm{~L}$

- $\quad$ Works department reservoir $=909,000 \mathrm{~L}$

- $\quad$ Total $=2,949,000 \mathrm{~L}$
Therefore, the capacity of the existing reservoirs is adequate for the present needs. These reservoirs should serve temporarily as service reservoirs. The current pipeline network should be either given a total overhaul or partial one so that they can be properly maintained. The issue of burst pipe has become a major reoccurring problem in the University due to that most of the pipes are over aged.

\section{CONCLUSION}

From the field work it was found out that the university water works lacks adequate data record keeping to actually determine fluctuations in the quantity of water demanded and supplied in order to determine when to pump more or less. Also the problems hindering improved water supply in the campus has been identified and analyzed and strategies for improved water supply discussed.

From observations it can be seen that UNN campus water supply system is capable of satisfying the water requirements of the university community. However, due to mismanagement and non-functioning boreholes and leaking pipes, the reverse is the case.

The average individual daily water need is $120 \mathrm{~L} /$ day. In the university total maximum estimation of about 2,500,000 L will be efficient for the university total water requirements. The 5 boreholes working for an average of $12 \mathrm{~h}$ each produces an average of about 1,620,000 L/day. It can therefore be deduced that the demand is greater than the supply.

To improve the current supply using the current facilities in the university then; let's say the 9 existing boreholes are made to work effectively for at least an average of $12 \mathrm{~h} /$ day and produces at least $27,000 \mathrm{~L} / \mathrm{h}$.

- Then the daily yield will be $12 \times 27,000 \times 9=$ 2,916,000 L or

- The 5 boreholes working effectively for an average of $22 \mathrm{~h}$ producing $27,000 \mathrm{~L} / \mathrm{h}$

- $\quad$ Then the daily yield will be $5 \times 22 \times 27,000=$ $2,970,000 \mathrm{~L}$

Proper research and geological investigations before siting boreholes and increasing the number of optimal working boreholes is the key to improving water supply in the university community.

\section{RECOMMENDATIONS}

In view to improving water supply in the university, we recommend the following: first of all, adequate funding of water facilities by the university authority should be enhanced as this will not only enable the 
department to purchase materials and equipment needed but also helps them to plan ahead of time and forestall impending mechanical problems.

Accurate record keeping and continuous research work should be done from time to time to always find the relationship between the quantity of water needed and supplied. This will help to know when to increase the number of boreholes and other water facilities.

More money can be saved by constructing new boreholes instead of trying to reactivate the old ones which might cost more money and still not increase efficiency. This will help reduce the overwork done by the existing working boreholes now.

The original water distribution system design for the campus should be followed effectively that is the water pumped from the boreholes should be sent to the treatment unit from there to the underground clear water tank then distributed to the reservoirs through the main lines with high pressure and then from the reservoirs to the consumers using gravitational force. This will stop bursting of pipes caused by the direct distribution from the underground clear water tank to the consumers through minor lines using high pressure.

There should be incentives and increased cooperation between the authorities and the personnel in the water works departments such that a mutual relationship exists between both. This will make workers to be more dedicated to their works.

The works department should be made to develop a proper maintenance culture. This will go a long way to reduce overhead cost of maintaining the systems after major breakdowns are allowed to occur. Adequate security should be provided against vandalisation, wastage, destruction of the installed facilities. Good record keeping attitude should be practiced and for this to happen, the pump house need to be provided with more educated staff.

The invention of PLC (Programmable Logic Controller) and SCADA (Supervisory Control and Data Acquisition) can help monitor and control water supply from a central station. It helps to easily detect faults and failures. This will ease stress and produce a more efficient output. Other water supply alternatives in the area should be looked into especially rainwater harvesting because with the availability of already built houses it will be less costly and easier to actualize.

\section{REFERENCES}

Agunwamba, J.C., 1995. Effective maintenance of rural boreholes. Water Resour., 6: 7-14.

Agunwamba, J.C., 2000. Optimal maintenance of rural bore-hole schemes. Niger. J. Eng. Manage., 1: 13-22.

Chima, G.N., 1989. Rural water supply in Isiala Ngwa LGA of Imo state. MSc Thesis, Department of Geography, University of Nigeria, Nsukka, Nsukka, Nigeria.

Eze, P.C., 1976. Housing problems in Nsukka. BSc Thesis, Department of Geography, University of Nigeria, Nsukka, Nsukka, Nigeria.

Hazen-Williams, 2009. Equation in fire protection systems. Limited Liability Partnership, USA.

Ubuoh, E.A., M.C. Obeta and E.C. Eze, 2014. Perception of sources, accessibility and consequences of domestic water supply in Mbaitoli local government area of Imo State, Nigeria. Adv. Life Sci. Technol., 18: 84-92.

WHO., 2018. Guidelines for Drinking-Water Quality. Vol. 1,/3rd Edn., World Health Organization, Geneva, Switzerland,. 